ISSN 2466-2232

Online ISSN 2466-2100

\title{
$\mathrm{Ni}$ 가 첨가된 고망간 용접봉의 입열량에 따른 인장 특성과 미세조직의 영향
}

\author{
한일욱 $\cdot$ 윤중길** $\cdot$ 이봉근 ${ }^{*}$ - 강정윤 ***, \\ *포스코 고망간 특화솔루션 프로젝트팀 \\ **부산대학교 융합학부 하이브리드소재응용전공 \\ ***부산대학교 재료공학과
}

\section{Effect of Tensile Properties and Microstructure on the Heat Input of Ni-Doped High Manganese Welding Wire}

\author{
Il-Wook Han*, Jung-Gil Yun**, Bong-Geun Lee*, and Chung-Yun Kang***, \\ *High Mnsteel Soulution Project Team, POSCO, Pohang, 37859, Korea \\ **Department of Hybrid Materials \& Machining Technology, Graduate School of Convergence Science, \\ Pusan National University, Busan, 46241, Korea \\ ***Department of Material Science and Engineering, Pusan National University, Busan, 46241, Korea
}

†Corresponding author : kangcy@pusan.ac.kr

(Received November 20, 2017 ; Revised December 6, 2017 ; Accepted December 19, 2017)

\begin{abstract}
The cryogenic high manganese steel is designed for tanks that transport liquefied natural gas, which has increased in demand globally. For this purpose, high manganese steel weld wire with ni added for Flux Cored Wire welding was welded under various heat input conditions. Then, a tensile test was measured to evaluate the mechanical properties. As a result, the heat input condition satisfying the required yield strength was $1.5 \mathrm{~kJ}$. The reason for this phenomenon is that a small amount of $\mathrm{Cu}$ contained in the base metal and the welding rod is generated in grain boundaries of $\mathrm{Cu}_{2} \mathrm{O}$ during solidification, causing liquefaction cracking.
\end{abstract}

Key Words : High manganese steel, Flux cored wire welding, Cryogenic

\section{1. 서 론}

전세계 에너지 수요는 2040년 까지 꾸준히 증가 할 것으로 예측 되고 있다. 특히 아시아지역 중 중국과 인 도의 인구 증가 및 경제 성장으로 인한 증가 추세와 함 께, 아프리카의 폭발적 인구증가가 이러한 예측을 뒷받 침 한다 ${ }^{1)}$. 여러 에너지원 중 석유자원이 주 에너지로서 의 역할을 2040 년도 까지 전체 에너지 사용량 차지 비 율에서 연 $0.7 \%$ 의 증가세를 보이며 담당할 전망이다. 하지만 에너지원 중 2 위를 차지한 석탄과 함께 두 연료 는 환경적인 오염물질을 다량으로 배출하는 문제점이
있다. 특히 이들이 주로 배출하는 $\mathrm{CO}_{2}$ 의 경우, 지구 온란화의 주범으로 지목되며, 그 성장세가 둔화되고 있 다. 한편 청청에너지로서 오래전부터 각광을 받고 있는 천연가스 $(\mathrm{LNG})$ 는 발전 재료 및 난방재, 그리고 최근 에는 차량용 연료로 주목을 받으면서 2040년 까지 년 $1.6 \%$ 의 증가세를 보일 것으로 예측되고 있다. 그래서 2025년에는 사용량이 석탄을 앞서, 석유에 이어 두번 째 에너지 자원으로 성장할 것으로 예상되고 있다. 이 와 함께 셰일가스의 발견은 전세계 에너지 구성에서 엄 청난 변화를 일으킬 것이며, 세일가스 최대 매장 지역 인 중국, 미국, 아르헨티나, 멕시코 등에서 에너지 공급 의 전통적인 판도를 뒤엎을 것으로 예상되고 있다. 셰 
일가스 개발로 천연가스의 황금시대가 도래할 것으로 예상하고 있다2). 이러한 천연가스는 대부분 생산처와 소비처가 많이 떨어져 있어 이송 및 보관이 필수적으로 필요하다 ${ }^{1)}$. 이러한 천연가스는 채굴 상태시 가스로 존 재하여 그 부피가 매우 커서 이송 및 보관이 매우 불편 한데, 이때 $-163^{\circ} \mathrm{C}$ 이하 극저온에서 $1 / 600$ 부피로 액 화시켜, 저장 및 이송을 용이하게 한다 ${ }^{3)}$.

한편 액화된 천연가스를 이송 및 저장이 가능한 탱크 제조에 사용되는 구조용 소재는 극저온 인성과 함께 열 팽창이 매우 적어야 한다. 그래서 현재 탱크용 소재로 사용되는 소재는 $9 \% \mathrm{~N}$ 강, 오스테나이트 스테인리스 스 틸, 알루미늄, 니켈기 합금, Invar합금 등이 적용되고 있다4). 하지만 이들 강재는 고급의 합금소재, 특히 $\mathrm{Ni}$ 가 대량 첨가 되어 있는데, 전세계 $\mathrm{Ni}$ 사용량 증가와 함 께 중국의 수출량 규제와, 인도네시아의 미가공 원석 수출 금지로 인하여 크게 인상되는 추세에 있고 ${ }^{5)}$, 탱크 제조시 공정 비용이 매우 높아 경제성이 떨어진다. 그 래서 최근에는 $\mathrm{POSCO}$ 에서 다른 합금계에 비해서 매 우 저렴한 $\mathrm{Mn}$ 을 다량으로 첨가하여 극저온 특정이 좋 은 Full 오스테나이트기지로 만든 고망간강을 개발, 적 용성을 검토하고 있다 ${ }^{6)}$.

한편 이렇게 개발된 고망간강을 극저온용 탱크 제작 용으로 사용하기 위해서는 용접부 인장시 최소 항복강 도가 $400 \mathrm{Mpa}$, 인장강도는 $560 \mathrm{Mpa}$ 이상이 되어야 하 고 ${ }^{6)}$ 또한 3 자세 용접이 필수적으로 필요하지만, 이러 한 고망간용 전자세 용접봉에 대한 연구는 미비한 실정 이다.

그래서 본 연구에서는 $\mathrm{LNG}$ 탱크제작용 극저온용 고 $\mathrm{Mn}$ 강에 적합한 전자세 $\mathrm{FCA}$ 용 용접재료 중 $\mathrm{Ni}$ 가 첨가 된 용접봉의 입열량에 따른 용접부의 기계적 특성 변화 및 미세조직의 변화를 연구하였다.

\section{2. 사용 재료}

Table 1은 실험에 사용된 모재와 용접봉 조성을 나 타낸 것이다. 용가재의 화학조성은 모재를 기본으로 하 되 모재에서 오스테나이트 안정화를 위해 첨가되었으 나, 용가재에 첨가 될 때에는 용접성을 나쁘게 하는 $\mathrm{C}$
와 $\mathrm{Mn}$ 은 적게 첨가하고, 대신 오스테나이트 안정화 원 소인 $\mathrm{Ni}$ 과 $\mathrm{Cu}$ 를 소량 첨가하여 용접성을 증가 시켰다. 그리고 결정립 미세화를 통하여 용접부 물성을 증가시 키기 위해 $\mathrm{Nb}, \mathrm{Ti}, \mathrm{Mo}$ 등의 미량원소를 첨가하였고, 인장 강도의 증가를 위해 $\mathrm{Cr}$ 도 소량 첨가하였다.

\section{3. 실험 방법}

Fig. 1은 용접을 실시한 모재의 형상과 용접 조건 그리 고 비드의 형상을 나타낸 것으로, 모재는 $12 \mathrm{~mm}$ 두께의 판재에 $50^{\circ}$ 의 개선각을 주었고, $3 \mathrm{~mm}$ 의 루트 갭을 설정 하였다. 용접 방법으로는 Flux Cored Arc Welding (이 하 $\mathrm{FCAW}$ )를 사용하였으며, 차폐 가스로 $80 \% \mathrm{CO}_{2}+$ $20 \% \mathrm{Ar}$ 를 사용하였으며 유량을 $20 \mathrm{~L} / \mathrm{min}$ 으로 적용하였 다. 입열량은 $1.0,1.5,1.8 \mathrm{~kJ} / \mathrm{mm}$ 총 3 가지로 실시 하였고, 입열량이 커지면서 비드 형상이 커지게 되어서, 그 결과 비드의 적층 수도 $1.0 \mathrm{~kJ} / \mathrm{mm}$ 시편은 $7 \mathrm{pass}$ $1.5 \mathrm{~kJ} / \mathrm{mm}$ 은 5 패스, $2.0 \mathrm{~kJ} / \mathrm{mm}$ 은 3패스로 달라졌다.

Fig. 2는 용접후 인장시편과 미세조직시편을 편취한 모양을 나타낸 것이다. 인장시편은 ASTM E08에 의거 한 사이즈로 편취 하였고 용접부가 모두 인장 시편에 포함 되도록 구성했다. 그리고 인장부 시편의 미세조직 분석을 위해서 인장시편과 거울면이 되도록 미세조직 분석용 시편을 제작 하였다. 이때 두 시편 사이를 방전 가공을 통하여 절단하여 손실율을 최소화하여 두 시편 이 최대한 유사한 미세조직을 가지도록 했다. 이렇게 편 취한 인장시편을 AWS D1.1에 의거하여 MTS Servo hydraulic Tensile Test Systems에 인장 속도를 $2 \mathrm{~mm} / \mathrm{min}$ 로 설정하여 사용 했다. 그리고 입열량별로 3 번의 인장시험을 실시하였다.
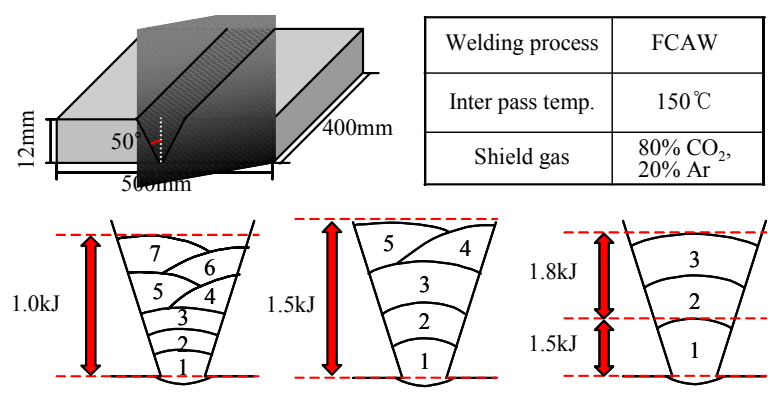

Fig. 1 Schematic diagram of welding conditions

Table 1 Chemical composition of high Mn steel \& weld metal

\begin{tabular}{|c|c|c|c|c|c|c|c|c|c|c|c|c|}
\hline & $\mathrm{C}$ & $\mathrm{Si}$ & $\mathrm{Mn}$ & $\mathrm{Ni}$ & $\mathrm{Cr}$ & $\mathrm{Mo}$ & $\mathrm{Al}$ & $\mathrm{Ti}$ & $\mathrm{V}$ & $\mathrm{Nb}$ & $\mathrm{Cu}$ & $\mathrm{Fe}$ \\
\hline Base metal & $<0.9$ & $<0.5$ & $<25$ & - & $<5.0$ & - & - & - & - & - & $<0.1$ & Bal. \\
\hline Welding Wire & $<0.5$ & $<1.0$ & $<25$ & $<5.0$ & $<3.0$ & $<1.0$ & $<0.01$ & & & & $<0.5$ & Bal. \\
\hline
\end{tabular}




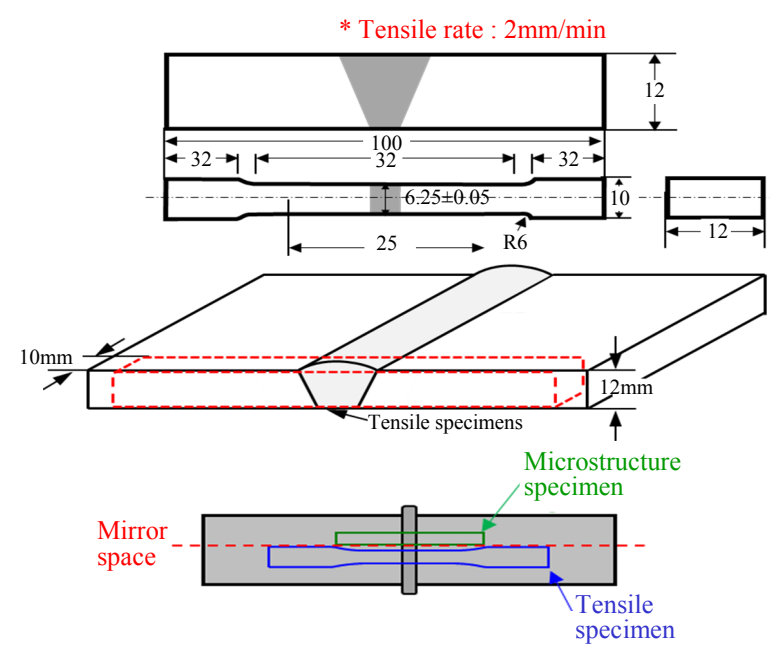

Fig. 2 Schematics diagram of tensile \& microstructure analysis specimens

\section{4. 실험결과 및 고찰}

\section{1 인장시험 결과}

Fig. 3은 각기 다른 입열량을 가진 용접부 시편을 앞 서 언급한 방법으로 인장시험을 실시하여 얻어진 결과를

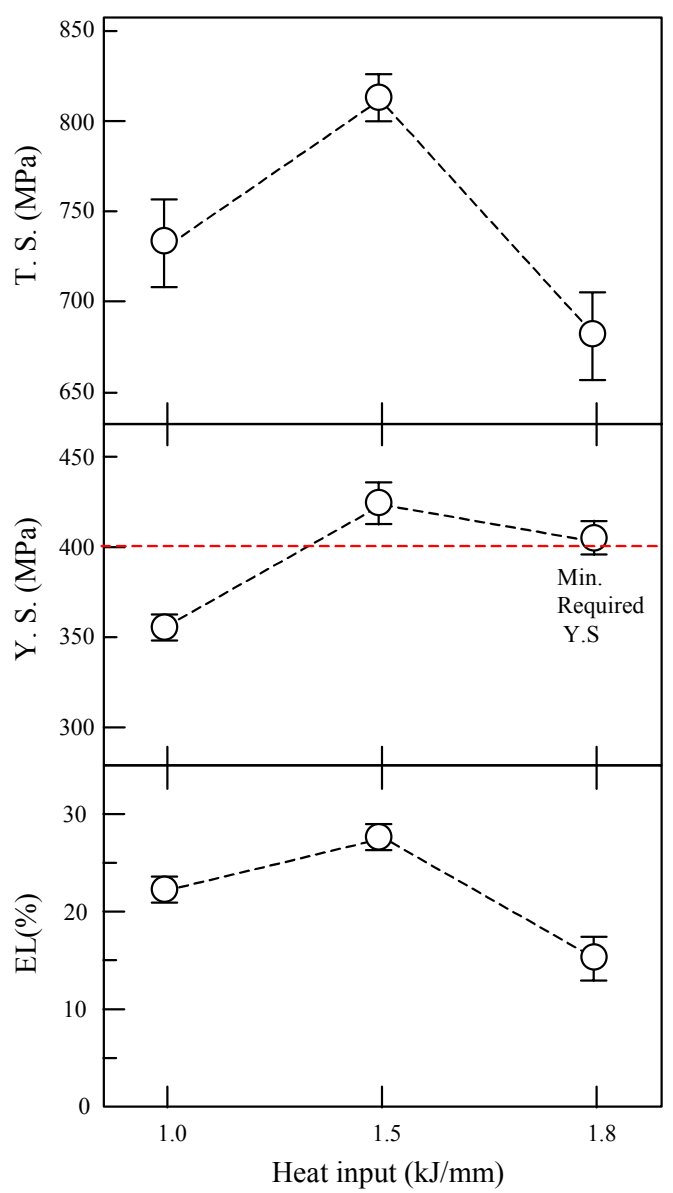

Fig. 3 The results of tensile test
나타낸 것이다. 인장과 항복강도 그리고 파단점까지의 연신율에서 최대치를 나타낸 입열 조건은 $1.5 \mathrm{~kJ} / \mathrm{mm}$ 시편이고, 그 다음으로 $1.0 \mathrm{~kJ}, 1.8 \mathrm{~kJ} / \mathrm{mm}$ 순으로 나타 났다. 한편 그림에서와 같이 3 조건 모두 최소인장강도 $560 \mathrm{Mpa}$ 를 크게 상회하는 인장 값을 나타냈다. 하지만, 최소항복강도 $400 \mathrm{Mpa}$ 의 경우 입열량 $1.0 \mathrm{~kJ} / \mathrm{mm}$ 의 인 장시편 3 개 모두가 만족하지 못하였고, $1.8 \mathrm{~kJ} / \mathrm{mm}$ 입 열 인장 시편에서 1 개 시편에서 만족하지 못하였다. 그 래서 최소 항복 강도를 만족하는 입열량 $1.5 \mathrm{~kJ} / \mathrm{mm}$ 시 편과 그렇지 못한 입열량 $1.0 \mathrm{~kJ}, 1.8 \mathrm{~kJ} / \mathrm{mm}$ 시편의 차 이점이 무엇인지 규명하기 위해서 파괴된 시편의 파면을 분석하였다.

\section{2 파괴된 인장시험의 파면 분석}

Fig. 4는 각 입열량 별로 파괴된 시편의 옆면과 실험 방법에서 언급한 대응 조직 시편을 Nital $6 \%$ 용액으로 에칭시켜 분석 한 것이다.

입열량 $1.5 \mathrm{~kJ} / \mathrm{mm}$ 와 $1.8 \mathrm{~kJ} / \mathrm{mm}$ 시편의 경우 대응 조직 시편과 대응해서 보았을 때 용접 비드 정중앙부의 회합부를 따라 파괴가 발생된 것을 알 수 있는 반면에 입열량 $1.0 \mathrm{~kJ} / \mathrm{mm}$ 시편의 경우에는 상층부 용융부 중 심과 왼쪽 모재부 사이 부분에서 왼쪽 모재쪽으로 사선 방향으로 균열이 존재하고, 이 균열의 끝부분에서 하단 부 쪽으로 쭉 이어진 균열이 모재와 용융부 사이 퓨전 라인을 걸친 후 하단부 쪽으로 파괴가 발생된 것을 알 수 있다. 입열량 $1.0 \mathrm{~kJ} / \mathrm{mm}$ 에서 다른 시편과 달리 이 상형태의 파괴가 일어난 이유를 알아보기 위해 파면의 불규칙한 높낮이에 크게 영향을 받지 않는 SEM을 이 용해서 인장시편의 파면을 저배율로 관찰하였다.

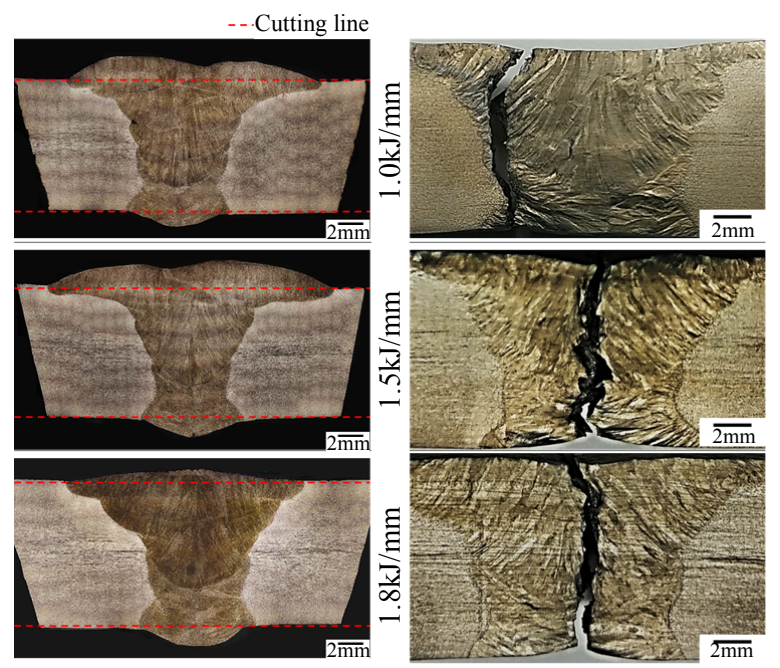

Fig. 4 The macroscopic image and fracture path of welded with different heat input specimens 


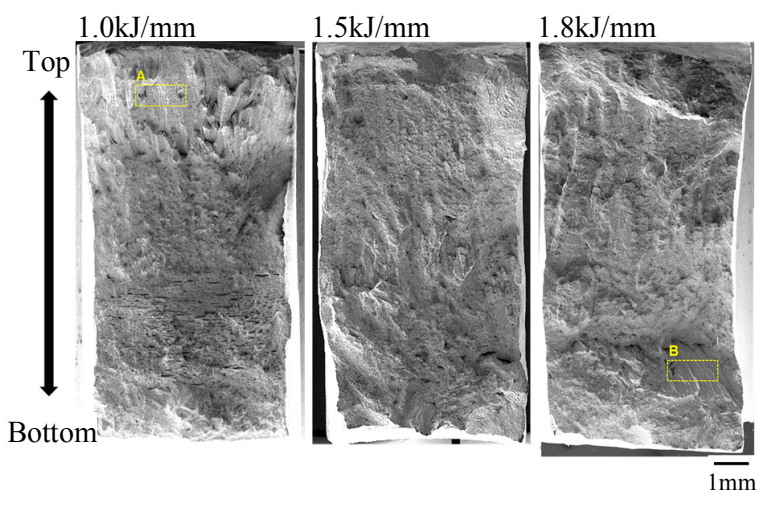

Fig. 5 Fracture surface Image of tensile specimens on various weld heat input.

Fig. 5는 입열량에 따른 인장시편의 파면을 저배율로 관 찰한 것이다.. 제일 높은 인장 특성을 보였던 $1.5 \mathrm{~kJ} / \mathrm{mm}$ 입열량 에서는 전체적으로 딤플형상의 연성파편으로 이 루어져 있는 것을 확인 할 수 있었다. 한편 이상 파괴 가 발생했던 $1.0 \mathrm{~kJ}$ 의 상단부와 $1.8 \mathrm{~kJ}$ 의 하단부에서 주지상정 모양의 파면이 발견 되었다. 이를 좀 더 상세 히 분석하고자 Fig. 5의 A,B를 Fig. 6에 더 높은 배 율로 확대하여 분석하였다. Fig. 6의 A의 경우 계곡과 봉우리가 교차된 모양이 반복되어 존재함을 알 수 있다. 반복된 모양중 한부분인 $\mathrm{A}$ 을 확대하여 관찰한 결과 봉 우리에서 한쪽은 일반적인 딤플 파면 (Normal Dimple $=$ N.D)으로 이루어져 있고 다른 한쪽은 표면이 얇은
액막(Liquid Film = L.F) 에 의해 덮여져 미끈하게 생 긴 형상이 발견 되었다. 그림 (c)의 입열량 $1.8 \mathrm{~kJ} / \mathrm{mm}$ 하단부 $\mathrm{B}$ 의 경우도 $\mathrm{A}$ 와 마찬가지로 봉우리와 계곡이 교차된 모양이 반복되어 나타나며, 액막으로 덮인 표면 과 일반적인 딤플이 혼재된 형상으로 나타남을 알 수 있다.

일반적인 딤플로 나타나는 부분과 액으로 덮인 부분 의 조성적 편차를 알기위해서 $\mathrm{EPMA}$ 를 통한 원소분석 을 실시하여 Table 2에 나타 내었다. 일반적인 딤플로 이루어진 쪽에서는 일반적인 용접부 조직의 평균 합금 조성과 유사하게 나타났으나, L.F에서는 N.D 대비 Ni 이 다소 많이 검출되었으며, $\mathrm{Cu}$ 와 $\mathrm{Si}$ 의 경우 모재에는 거의 없는 원소이나, 액막에서는 매우 많이 검출되었다. $\mathrm{S}$ 와 P 또한 N.D에서는 검출 되지 않았으나 L.F에서 는 검출되었다. 이로서 액막의 정체가 $\mathrm{Cu}-\mathrm{Si}$ 가 부화된 $\mathrm{S}, \mathrm{P}$ 함유상인 것을 알게 되었다. 이러한 액막이 미세조 직 상에서는 어떠한 위치에 어떤 형태로 존재하는지 알 아보고 이러한 액막이 인장시 어떠한 역할을 하는지 규 명하기 위해 인장시편의 대응 조직 시편을 분석하였다.

\section{3 대응 미세조직에서의 액막 분석}

Fig. 7은 인장시편의 대응 조직시편에서의 사선형태 의 균열이 발생된 부분과 대응되는 부분의 미세 조직을 Alkaline 에칭을 적용 하여 나타 낸 것이다.
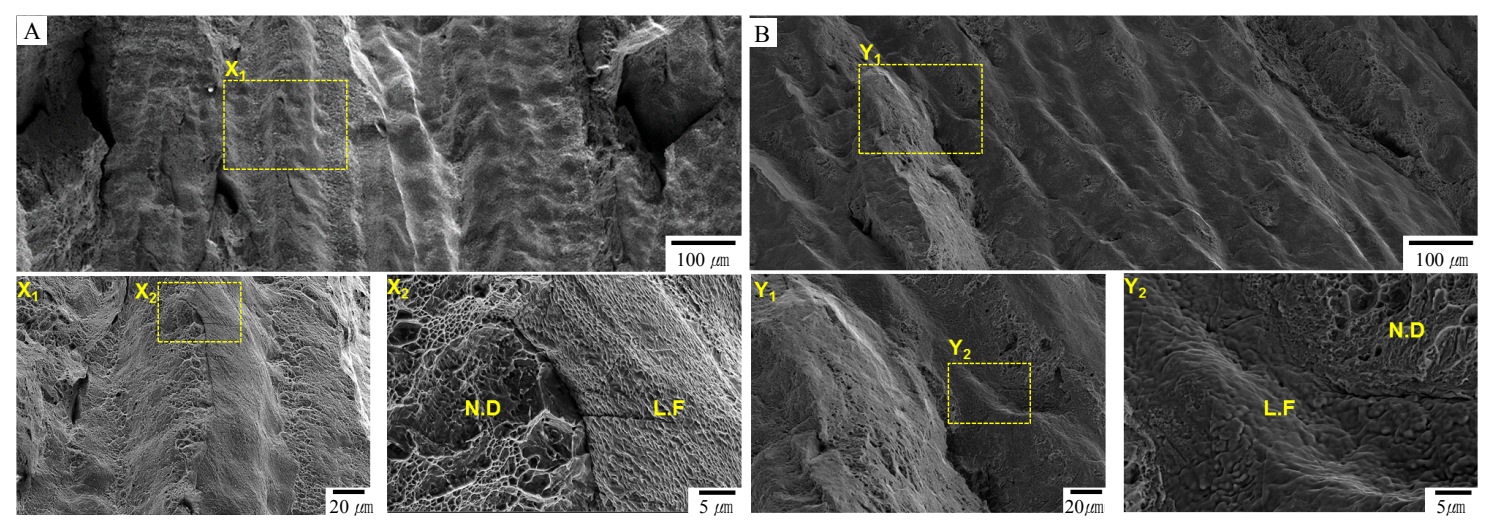

Fig. 6 Fracture surface analysis on abnormal fracture surface in Fig. 5

Table 2 Chemical composition of high Mn steel \& weld metal in Fig. 6

\begin{tabular}{|c|c|c|c|c|c|c|c|c|c|c|}
\hline wt(\%) & $\mathrm{C}$ & $\mathrm{Si}$ & $\mathrm{Mn}$ & $\mathrm{Ni}$ & $\mathrm{Cu}$ & $\mathrm{Cr}$ & $\mathrm{S}$ & $\mathrm{P}$ & $\mathrm{O}$ & $\mathrm{Fe}$ \\
\hline N.D1 & 0.30 & 0.74 & 19.11 & 7.07 & - & 1.59 & - & - & 1.11 & Bal. \\
\hline N.D2 & 0.29 & 0.68 & 21.94 & 3.59 & - & 1.40 & - & - & 0.90 & Bal. \\
\hline L.F1 & 0.38 & 2.11 & 20.87 & 8.12 & 2.27 & 1.85 & 0.23 & 0.32 & 0.96 & Bal. \\
\hline L.F2 & 0.68 & 2.04 & 18.74 & 10.93 & 1.38 & 1.81 & 0.21 & 0.33 & 0.86 & Bal. \\
\hline L.F3 & 0.98 & 1.82 & 18.30 & 6.29 & 1.21 & 1.43 & 0.21 & 0.28 & 0.66 & Bal. \\
\hline L.F4 & 1.27 & 1.57 & 22.41 & 7.36 & 1.64 & 1.72 & 0.44 & 0.24 & 0.95 & Bal. \\
\hline
\end{tabular}




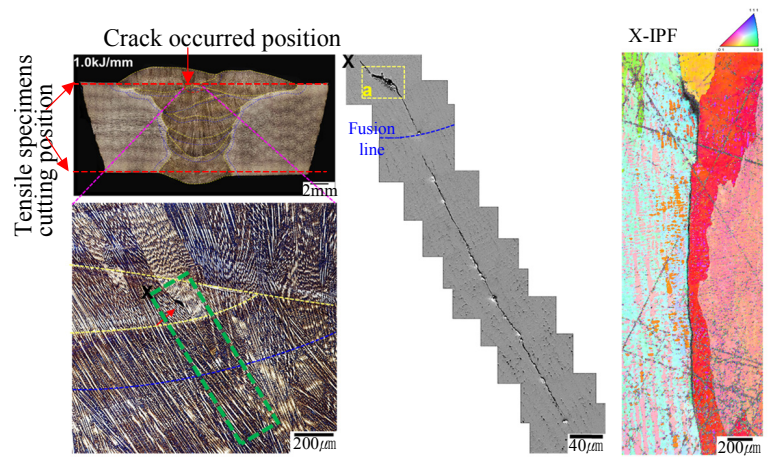

Fig. 7 Analysis of cracks in corresponding microstructure specimens

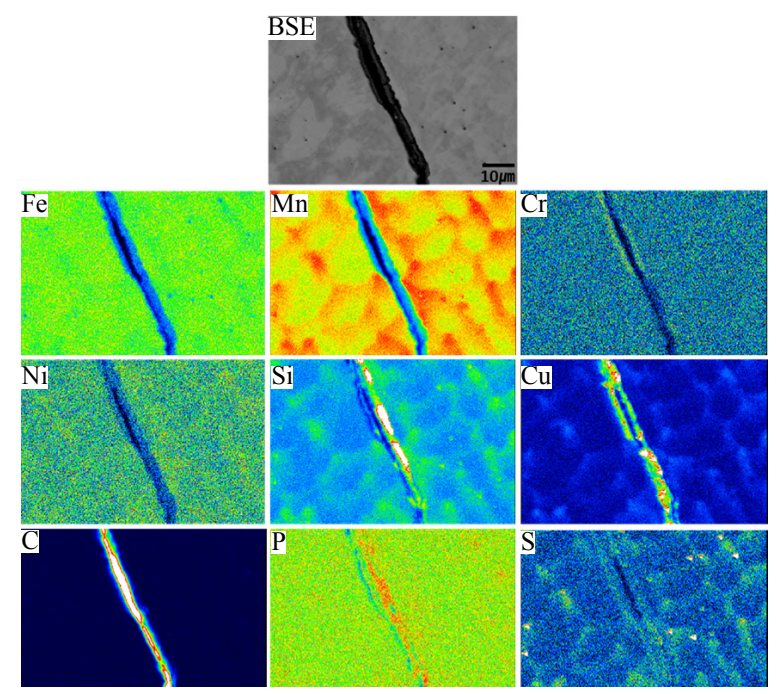

Fig. 8 Analysis of the black band on EPMA mapping

보이는 것과 같이 미세조직 시편에서도 사선형태의 미 세균열이 발생되어 있고 이부분은 용접부가 후행패스에 의하여 재가열된 부분으로 보여 진다. 이러한 미세 균 열이 일어난 곳의 위치 파악을 위해 미세연마를 통하여 에칭만을 제거하고 $\mathrm{EDAX}$ Hikari $\mathrm{EBSD}$ 를 이용하여 $\mathrm{EBSD}$ 분석을 실시하였다. 그 결과 IPF 이미지를 통하여 미세 균열이 발생된 부분이 결정입계임을 알수 있었다.

Fig. 8에는 미세 균열부의 합금 원소 분포를 알기위 해 Jeol JXA-8530F EPMA를 통해 분석한 EPMA $\mathrm{BSE}$ 이미지와 함께 면분석 결과를 나타내었다.

모재부의 경우 $\mathrm{BSE}$ 이미지에서 응고 조직과 아닌 부 분으로 나누어지며, $\mathrm{Mn}, \mathrm{Ni}, \mathrm{Si}, \mathrm{Cu}, \mathrm{S}$ 가 응고조직부 에 일반 기지보다 편석되어 있는 것을 알 수 있다. 미 세 균열부의 모재와 가까운 양쪽에 진한 회색빛깔 밴드 가 존재하고 중심부에는 검은색 밴드가 존재함 하는데, 검은색 밴드의 경우 $\mathrm{C}$ 가 부화되어 있고, 회색 밴드의 경우 $\mathrm{Si}, \mathrm{Cu}$ 가 많이 편석되어 있고 $\mathrm{P}, \mathrm{S}, \mathrm{Cr}$ 다소 편 석되어 있다. 반면에 $\mathrm{Fe}, \mathrm{Mn}, \mathrm{Ni}$ 는 결핍되어 있는 것
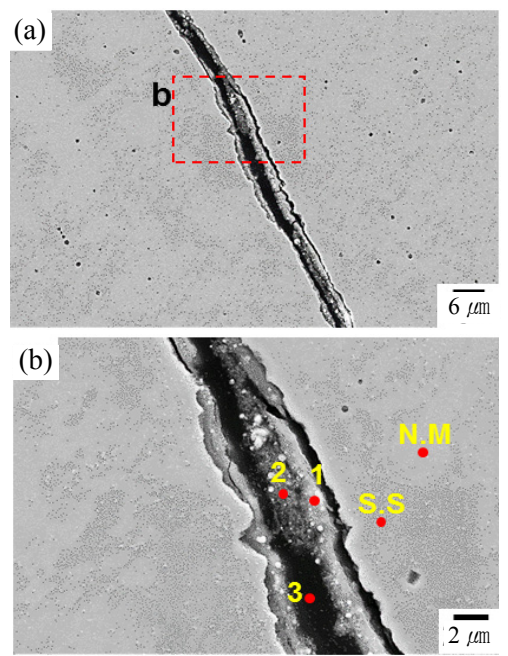

\begin{tabular}{|c|c|c|c|c|c|c|c|c|c|c|}
\hline wt(\%) & $\mathrm{C}$ & $\mathrm{Si}$ & $\mathrm{Mn}$ & $\mathrm{Ni}$ & $\mathrm{Cr}$ & $\mathrm{S}$ & $\mathrm{O}$ & $\mathrm{P}$ & $\mathrm{Cu}$ & $\mathrm{Fe}$ \\
\hline N.M & 0.32 & 0.68 & 19.82 & 3.63 & 1.40 & - & - & - & - & \\
\hline S.S & 0.66 & 0.82 & 24.34 & 4.58 & 1.23 & 0.11 & - & - & 0.31 & Bal. \\
\hline 1 & 5.96 & 1.15 & 13.65 & 2.79 & 2.19 & 0.32 & 8.34 & 0.32 & 13.83 & Bal. \\
\hline 2 & 18.55 & 1.47 & 10.71 & 2.69 & 1.21 & 0.33 & 8.13 & 0.24 & 10.58 & Bal. \\
\hline 3 & 47.39 & 1.69 & 9.11 & - & 1.27 & 0.20 & - & - & - & Bal. \\
\hline \multicolumn{18}{c|}{ S.S : Solidification Structure } \\
N.M : Normal Matrix
\end{tabular}

(c)

Fig. 9 Analysis of the black band on EPMA quantitative analysis

을 알 수 있다.

좀 더 정확한 원소 편차를 알아보기 위해 11 개의 원 소에 대한 $\mathrm{EPMA}$ 정량 분석을 실시한 결과를 Fig. 9 에 나타 내었다. 용접부 기지조직의 경우 응고조직 부 분과 일반 기지 부분으로 나누어 분석 하였다. 그 결과 Fig. 8 과 같이 응고 조직에서 $\mathrm{Mn}, \mathrm{Ni}, \mathrm{Si}, \mathrm{Cu}, \mathrm{S}$ 가 더 편석된 것으로 나타 났다. 회색 밴드의 경우 $\mathrm{Cu}, \mathrm{C}$, $\mathrm{O}, \mathrm{Si}, \mathrm{S}, \mathrm{P}$ 가 일반 기지 대비 많이 나타 났고, 이는 앞서 Table 2 의 L.F 분석 결과와 일치한다. 그래서 회색밴드는 파면에서 액막과 일치함을 알 수 있다. 이 로서 미세균열의 발생원인이 후행 패스에 의한 입열으 로 인하여 입계의 $\mathrm{Cu}-\mathrm{Si}$ 와 $\mathrm{S}, \mathrm{P}$ 의 화합물이 융해되어 액막이 발생되었고, 이러한 액막이 찢어지면서 발생되 었음을 알 수 있었다. 한편 중심부의 검은 밴드의 경우 $\mathrm{C}$ 가 $47.39 \%$ 로 매우 많이 존재하고 있음을 알 수 있는 데, 이는 파면의 액막에서는 이러한 $\mathrm{C}$ 이 부화된 부분이 나타나지 않은 것으로 보아 마운트시 사용한 레진의 침 입으로 인하여 발생된 것으로 사료된다.

그래서 액막과 검은 밴드의 정확한 상판별을 위해서 $\mathrm{EPMA}$ 를 분석한 부분을 $\mathrm{FIB}$ 로 편취하여 $\mathrm{TEM}$ 을 통 한 분석을 실시하였다 


\section{4 액막과 검은띠의 상동정 및 발생원인}

Fig. 10은 앞서 EPMA 분석위치에서 FEI의 Scios를 이용 FIB를 편취한 모습과 편취한 시편을 FEI의 TALOS $\mathrm{F} 200 \mathrm{X}$ 를 이용하여 $\mathrm{HAADF}$ 이미지를 분석한 것이다.

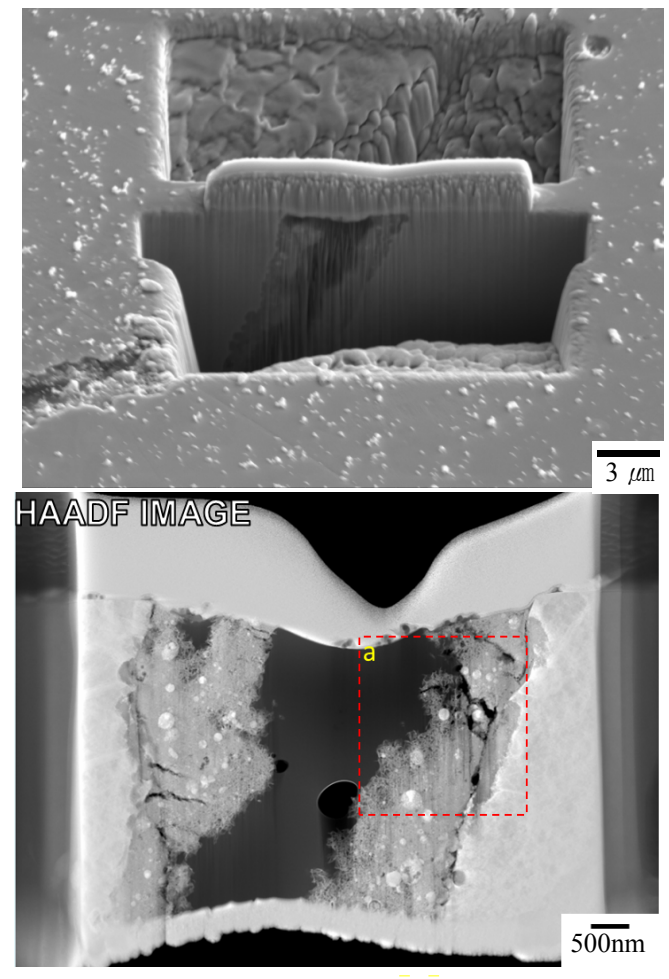

Fig. 10 Black band TEM specimen made by FIB
FIB 편취 시편에서 알 수 있듯이 액막과 검은띠는 깊 이 방향으로도 연속적으로 존재하는 것을 알 수 있다. 그리고 $\mathrm{HAADF}$ 이미지 분석을 통해서 액막 속에는 기 지와 유사한 점상들과 액막과 비슷한 밝기를 가진 점상 이 공존하고 있음을 알수 있다. 이는 점상이 모재와 유 사 조직의 점상과 액막과 유사한 조직의 점상 2 가지로 이루어져 있음을 나타낸다. 한편 검은띠의 경우 기지 및 액막과 전혀 다른 조직임을 알 수 있다. Fig. 11는 Fig. 10의 a 부분을 확대 후 Super EDS를 통해 면 분석을 실시하였다. 그 결과 액막 부분의 경우 $\mathrm{Cu}, \mathrm{O}$ 가 부화된 것을 알 수 있는데, 이는 저융점 원소가 녹 았다 굳으면서 산화되어 그런 것으로 생각 된다. $\mathrm{S}, \mathrm{P}$ 의 경우 산화시 기화 되므로 액막 부분에서 많은 량의 부화는 일어나지 않는 것으로 생각 된다. 액막 속 점상 의 경우 $\mathrm{Fe}$ 가 부화된 점상과 $\mathrm{Cu}$ 가 부화된 2종류의 점 상이 존재함을 알 수 있는데, 이는 앞서 분석했던 기지 와 유사한 점상이 $\mathrm{Fe}$ 가 부화된 점상이고, 액막과 유사 한 점상이 $\mathrm{Cu}$ 가 부화된 점상임을 알 수 있다. 이렇게 $\mathrm{EDS}$ 맵핑을 통하여 $\mathrm{FIB}$ 편취부에는 부화된 원소에 따라 기지, 액막, 액막 속 점상 2 가지 $(\mathrm{Fe}, \mathrm{Cu}$ 계 $)$ 그 리고 검은띠 5 가지로 나눌 수 있었고, 이에 따라FEI의 TALOS F200X와 Jeol JEM-2100F를 이용하여 5가 지 대표 형상에 대한 Pattern 분석을 실시한 결과를 Fig. 12에 나타 내었다.

Fig. 12에 따르면 기지 조직의 경우 고망간강의 주 요 조직인 $\mathrm{Fe}$-오스테나이트임을 알 수 있다. 액막이라
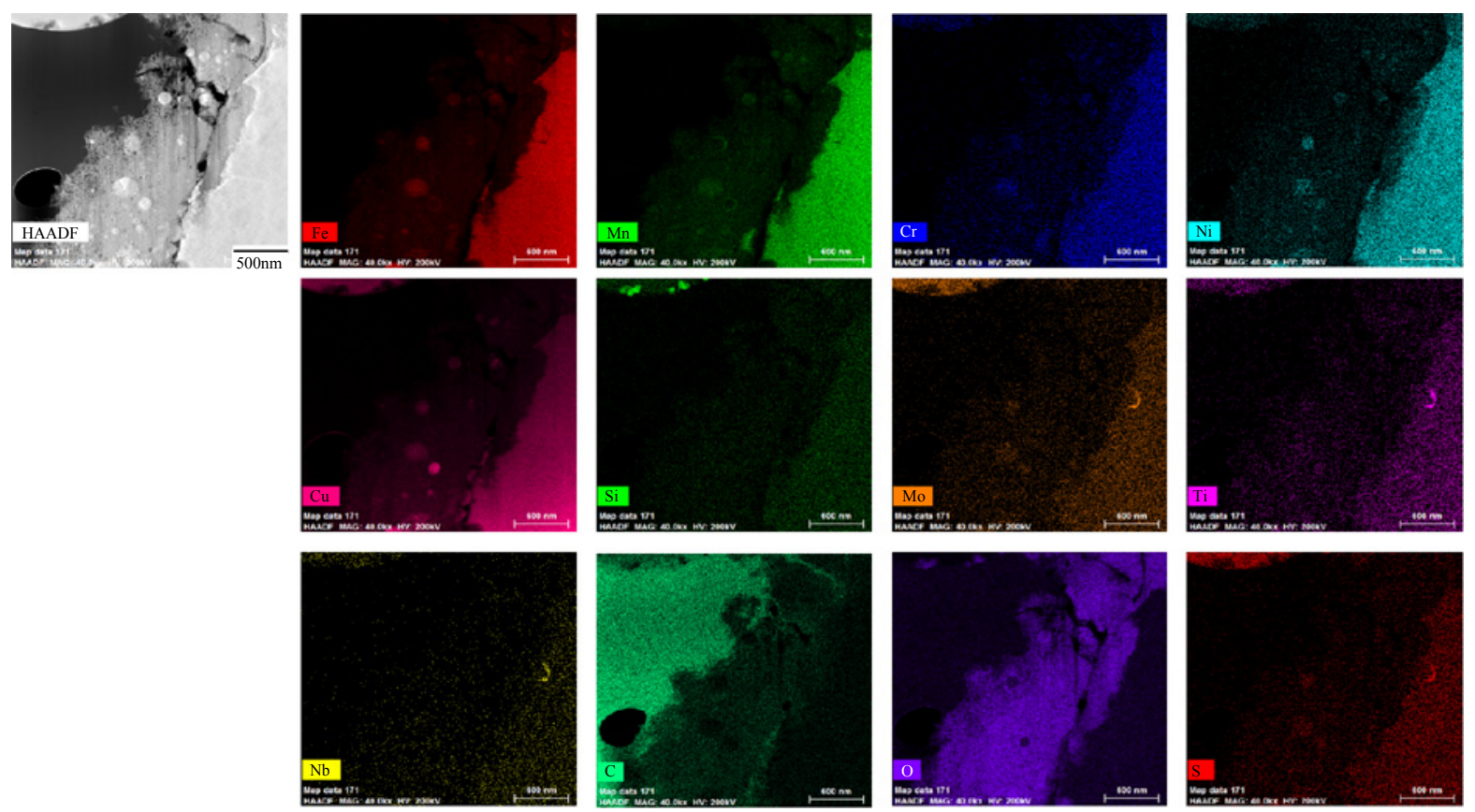

Fig. 11 Results of EDS mapping data in Fig. 10-a 

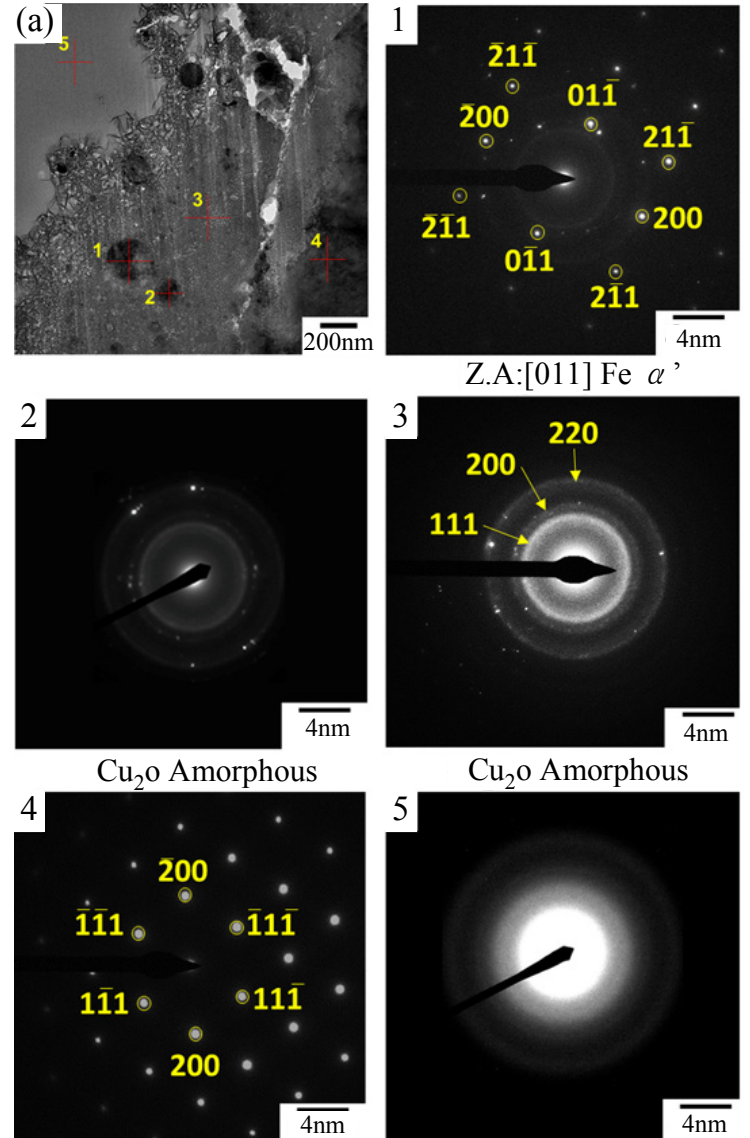

Z.A:[011] Fe- $\gamma$

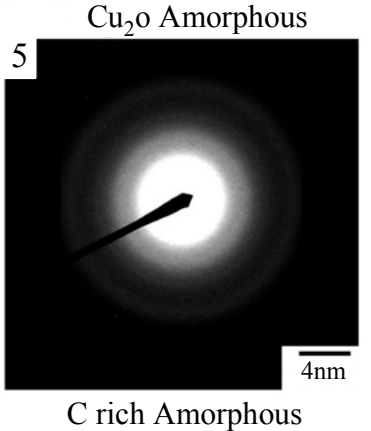

Fig. 12 SAED patterrn analysis of 5 types represented phase in Fig. 10-a

고 생각한 회색 밴드의 경우에는 링 패턴으로 나타나는 것으로 보아 비정질임을 알 수 있으며, $\mathrm{D}$ 값을 통해 분 석 결과 $\mathrm{Cu}_{2} \mathrm{O}$ 임을 알 수 있다. $\mathrm{Cu}$ 부화된 점상의 경 우에는 액막과 동일한 $\mathrm{Cu}_{2} \mathrm{O}$ 비정질이나, 아직 회절점 이 액막에 비해 선명하게 나타나는 것으로 보아 비정질 화가 덜된 것으로 보인다. $\mathrm{Fe}$ 부화된 점상의 경우에는 $\mathrm{Fe}^{-}$마르텐사이트로 나타나는데, Fig. 8과 같이 액막 속의 오스테나이트 안정화 원소인 $\mathrm{Mn}$ 과 $\mathrm{Ni}, \mathrm{C}$ 량이 기 지 대비 줄어든데다, 냉각시 급랭되면서 마르텐사이트 로 변태된 것으로 보인다. 검은띠의 경우 링패턴의 형 상이나 링의 테두리가 선이 아닌 밴드로 나타남으로서 $\mathrm{C}$ 가 완전한 비정질로 존재하는 것이 특징이다.

\section{5 이상 파괴기구 고찰}

Fig. 13는 입열량에 따른 인장시편과 대응되는 각 미세조직 시편 미세조직 사진과 정중앙 부로 파괴가 일 어나는 이유에 대한 설명을 나타낸 것이다. 그림에서 알 수 있듯이 모든 미세조직에서 정중앙부에 회합부가
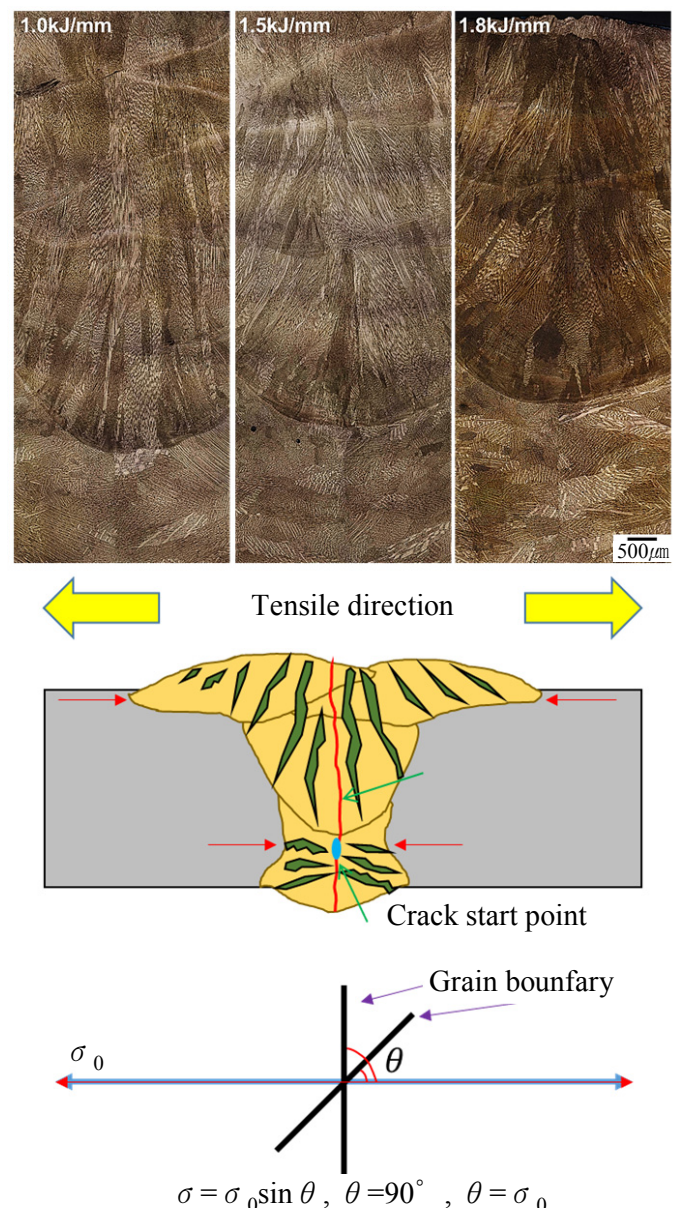

Fig. 13 The reason for fracture occurred in center grain boundary

존재하는 것을 알 수 있다.

이러한 회합부는 인장 방향과 수직 $\left(90^{\circ}\right)$ 이 되기 때문 에 다른 결정립계와 달리 응력이 가해 질 때 $100 \%$ 의 응 력을 받게 되어 우선적으로 슬립이 일어나게 된다. 한 편 고망간강 용접부는 $\mathrm{Mn}$ 이 다량으로 포함되어 있어, 용접 후 응고하는 동안 $\mathrm{Mn}$ 의 기화현상이 발생하며, 높 은 합금원소 함유로 인하여 합금원소의 편석과 결핍현 상이 발생한다. 그리고 오스테나이트 안정화 원소인 C, $\mathrm{Mn}$ 이 결핍된 영역에는 $\varepsilon$ 상 ( $\mathrm{HCP})$ 을 형성하며, 이로 인해 기계적 특성이 저하된다 ${ }^{7-10)}$. 그래서 모재보다 합 금조성 및 제조 공정 차이에 의해서 항복\&인장강도와 연신율이 낮게 된다. 그래서 응력 구속현상으로 인하여 연화부인 용융부가 우선 슬립이 일어나게 된다. 이때 인장시편 상부의 경우 연화 영역이 넓어 응력이 분산되 나, 루트부 부근의 용접부가 좁은 영역의 경우 연화영 역이 좁으므로 일부 구간에 응력이 집중되어 빠르게 슬 립이 일어나게 된다.

Fig. 14는 입열량에 따라 인장 시편이 파괴되는 모습 을 모식도화 한 것이다. 입열량 $1.0 \mathrm{~kJ}$ 의 경우 회합부 


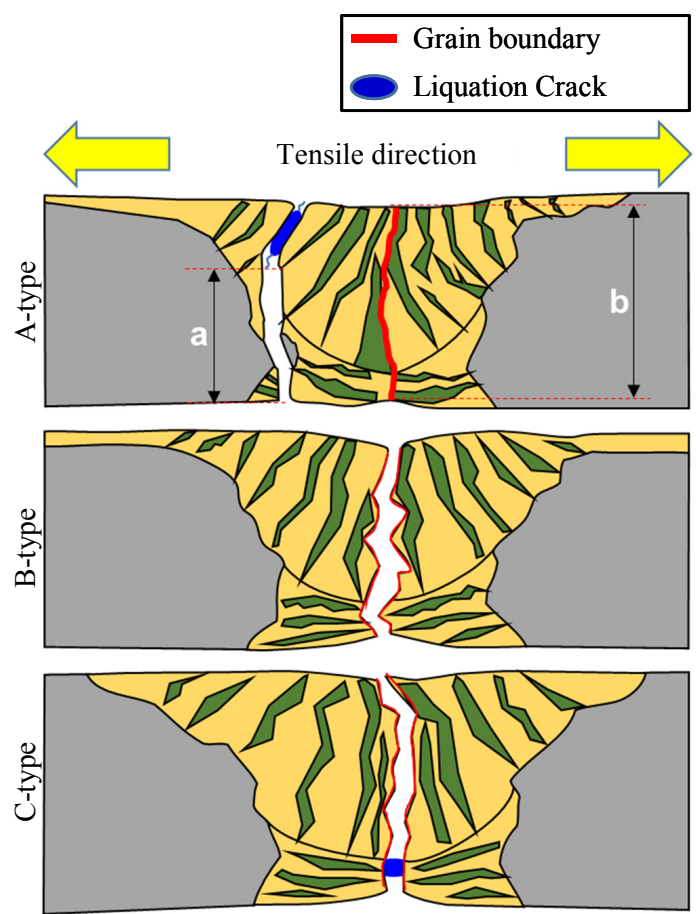

Fig. 14 Schematic diagram explaining the cause of nonideal failure

와 융점이 낮은 $\mathrm{Cu}_{2} \mathrm{O}$ 에 의한 ${ }^{11)}$ 액화 균열이 발생되어 있는 두 곳 모두에서 슬립이 일어나다가 액화 균열이 발생된 부분에서 액화균열을 따라 사선형태로 크랙이 커진다. 이때 이 부분의 단면적 a가 회합부 단면적 $\mathrm{b}$ 보 다 적어지는 시점에서 응력이 집중되고 이로 인하여 비 정상적인 파괴가 발생되면서 항복강도와 인장강도가 감 소하게 되는 것이다. 또한 입열량 $1.8 \mathrm{~kJ}$ 의 경우 회합 부 하단부의 응력이 집중되는 부분에서 액화 균열이 발 생되어 미세 균열이 생성되어있었고 그로 인한 노치 효 과로 인하여 급격한 인장강도의 하강이 발생된 것으로 생각 된다. Fig. $14 \mathrm{C}$ 타입의 파괴 모식도가 이를 설 명한다. 반면에 $1.5 \mathrm{~kJ}$ 의 경우 $1.0 \mathrm{~kJ}$ 과 $1.8 \mathrm{~kJ}$ 과 달리 액화 균열에 의한 이상 파괴 없이 회합부 부근에 응력 이 집중되어 슬립이 시작되고, 인장강도 도달 후 단면 감소가 발생되었고, 정상적인 파괴가 일어났기에 높은 항복\&인장강도와 연신율을 얻을 수 있었던 것으로 보 인다. 이는 액화균열 발생여부와 위치가 입열량 보다 더 인장 특성에 더 밀접한 영향을 주는 것으로 생각된다.

\section{5. 결 론}

$\mathrm{Ni}$ 가 첨가된 고망간 $\mathrm{FCAW}$ 용접봉의 입열량에 따른 인장 특성과 미세조직의 영향을 연구한 결과 $\mathrm{FCAW}$ 용 용접봉과 고망간강 강재에 함유된 미량의 $\mathrm{Cu}$ 와 불순물 이 결합하여 용접시 융점저하 원소로 작용 된다. 이것 들이 고온에서 이러한 액화 균열을 야기하여 미세한 균열 을 만들고 인장시 항복강도와 연신율을 저하시킨다.

ORCID: Il-Wook Han: http://orcid.org/0000-0002-1179-3339 ORCID: Jung-Gil Yun: http://orcid.org/0000-0001-8237-1400 ORCID: Bong-Geun Lee: http://orcid.org/0000-0002-9852-304x ORCID: Chung-Yun Kang: http://orcid.org/0000-0003-1122-5320

\section{References}

1. MOBIL, Exxon. The 2013 outlook for energy. a view to 2040, Irving, Exxon Mobil, (2012)

2. BIROL, Fatih, et al. Golden Rules for a Golden Age of Gas, World Energy Outlook Special Report on Unconventional Gas, International Energy Agency, 12 (2012),

3. KOTZOT, Heinz J., Overview of the LNG Industry Seminar, Gas Treatment, Liquefaction, and Storage. In: GPA Convention, San Antonio, (2003)

4. OLSON, David L., (ed.). ASM handbook, welding, brazing, and soldering, Asm Intl, (1993)

5. SHIM, Hye-Jeong, Trade Focus, In: IIT, 62 (2014),

6. CHOI, Jong K., et al. High manganese austenitic steel for cryogenic applications, In: The Twenty-second International Offshore and Polar Engineering Conference, International Society of Offshore and Polar Engineers, (2012)

7. RONCERY, Laís Mújica, et al. Welding of twinning- induced plasticity steels, Scripta Materialia, 66(12) (2012), 997-1001

https://doi.org/10.1016/j.scriptamat.2011.11.041

8. TOMOTA, Y., et al. Microstructural dependence of Fehigh Mn tensile behavior, Metallurgical Transactions A, 17(3) (1986), 537-547 https://doi.org/10.1007/BF02643961

9. TOMOTA, Y., et al. The relationship between toughness and microstructure in Fe-high Mn binary alloys. Metallurgical Transactions A, 18(6) (1991), 1073-1081 https://doi.org/10.1007/BF02668556

10. JEONG, Bo-Young, et al. Characteristics of Dissimilar $\mathrm{CO}_{2}$ Laser Welding for High Mn Steel and Low Carbon Steel, Journal of Welding and Joining, 28(3) (2010), 36-41 https://doi.org/10.5781/KWJS.2010.28.3.036

11. MASSALSKI, T. B, Binary Alloy Phase Diagrams, American Society for Metals, Metals Park, OH (1990), 1447 